\title{
Poética e Interculturalidad
}

La poesía trasciende todas las artes en tanto impera en el reino infinito de la imaginación.

F.V. 


\section{Prosemas}

Gloria Elena Palacios Mora' ${ }^{1}$

\section{Leche materna}

Niñita de ojos escarcha, deja que marche rumbo al trabajo. No me detengas con tus manitas pequeñas y esas ropitas de color pastel. Tomaré el bus y te iré pensando, mientras mis pechos derraman la leche que no podré darte y en cambio, se absorbe en el protector de esponja que oculta mi sostén.

\section{Jacuzzi}

Mano con mano se juntan siempre, piel con piel en el jacuzzi. Espacio desnudo, centro de espumas, vibración y dominio. Los cuerpos fueron llevados hacia la cama y sin darse cuenta, el agua ascendía. La espuma derramada en toda la habitación empapaba con derroche el sudor de los cuerpos.

${ }_{1}$ Comunicadora Social. Originaria de Masaya, la Ciudad de las Flores. Tiene publicado su primer libro "La Mujer Andante" y ha sido publicada en antologías, revistas, suplementos y páginas Web literarias. Es miembro de la Acción Creadora Intercultural (ACIC). 


\section{Delvin Mendoza Olivar}

\section{Imágenes}

La hoja cae al vacío.

Suspiró su último instante, se desprendió de su peciolo.

Cayó en lo más hondo de su vida.

Sintió el caer incierto,

aguardado en sus noches gélidas, donde centauros y chacales

pisotean su envés, cuando bacterias toquen su limbo, y el oxígeno acabe en su yerto carbónico. Amiga del viento y sonar de silbidos intensos.

Marchar de huracanes, caminar de hormigas a cuestas, hongo blanco, anochecer de inviernos...

¡Camino a la eternidad!

\section{Enero}

El viento corre

con piernas de atleta.

Apresurado busca en cada rincón

la aventura que empapa

de lluvia la comarca,

con mirada taciturna

de las serranías...

¡Conmigo descansa

la tristeza de mi corazonada!

\section{Luna}

Quietud de la noche.

Noche de tirante lumbre de luna.

Las nubes te arrastran

a un camino incierto.

Un enorme nubarrón...

Oculta la generosidad.

Siete centinelas vigilan la marcha, ¡ojos abiertos!

Una lengua extraña de luz...

Disipa la penumbra.

Te asomas imponente, ¡más brillante!

Desvaneciste...toda suciedad, ¡quieta...te mueves orgullosa!

Con la estrella.

Amiga inseparable.

\section{Sigo remando}

\author{
Quién con intenso toque \\ besó esta tarde mis mejillas. \\ Se despidió sonriente. \\ Quién reclama mi felicidad. \\ Cuándo volaste mariposa bella. \\ Te marchaste de la playa... \\ Cuántas lágrimas corrieron. \\ Cuanta dicha me has deseado. \\ ¡Cuanta suerte! \\ Te fuistes con la razón \\ entre tus brazos. \\ Te busqué en mi ansiedad. \\ Encontré la soledad, \\ sentada a la entrada, \\ en mi corazón. \\ Tu presencia, falta \\ al glorioso instante. \\ Despídeme con un beso. \\ Seguiré remando en el mar.
}




\title{
Hoy es el día del agua
}

\author{
Bajo la cobijada sombra \\ de autótrofos árboles, \\ y un placentero río de aguas \\ cristalinas... \\ Donde discurren avecillas \\ a chapotear, basiliscos \\ espantados por el caer \\ de una hoja y culebras \\ buscan su temperamento \\ en el interior. \\ El agua con su corriente \\ me invita a gritar al mundo: \\ que no abastece en nuestras \\ cocinas, que llora un mar \\ de desierto en invierno. \\ Que no encuentran acogimiento \\ sus mantos... \\ La chicharra murió antes de llegar \\ la lluvia. Y el niño, de Pakistán \\ y la India no calmó su sed. \\ Nuestra naturaleza clama \\ al unísono: ¡Basta ya! \\ Seres pensantes, no eliminen \\ nuestra flora, ni ríos, humedales... \\ que vuestros males aumentan. \\ Y nuestro enojo se devuelve \\ en una eminente destrucción. \\ No puedes seguir opacando \\ sonrisas de niños, \\ no puedes restringir \\ que se llenen sus cántaros. \\ No puedes derretir \\ mis casquetes polares y hacer \\ que las fuentes del abismo \\ hagan temblar con destrozos \\ vuestros edificios. \\ No puedes llenar con lamento \\ nuestro planeta tierra. \\ ¡No puedes! ¡No puedes!
}




\section{Del poemario inédito "Pepitas de palabra"}

Alba Rosa Pastora

\section{Despedida a Edgard}

¡Ha muerto el poeta!

¡Ha muerto el poeta!

El que brotó del elemento líquido

y versó los enigmas del Cailagua.

El que limó la palabra

y en parto novedoso

nació la brevedad.

El errante peregrino:

cantor de mitos ancestrales,

al paso pasea por las galaxias

entonando himnos de eternidad.

\section{Desove}

Abrazada al báculo del tiempo, pretendiendo perennizar su especie, busca el vientre de la playa.

Ignorancia.

Hambre.

¡Aborto!

La extinción es inevitable.

\section{Gaza}

Hoy es la danza del humo holocaustico, abraza la tierra el aroma a pólvora y misil, se eleva el humo con olor a piel quemada.

Hoy es la angustia, el dolor, la injusticia saltando muros.

Danza la muerte al son de los proyectiles, envuelta en fósforo blanco, abriendo entrañas, sembrando gritos y lamentos, engulle el terror sus víctimas, ahogada en las alambradas se quedó la Paz. 


\section{Niños poetas de la Florida, Nueva Guinea}

\section{Naturaleza}

Naturaleza pura. Tus manos se cayeron.

Tus ojos derramaron lágrimas.

Tus pies se zafaron...

Sólo queda reconocer:

El que te cuida merece la vida.

\section{El mar}

El mar como un diamante brilla en el cielo.

Las nubes se ven por las colinas. Los ríos admirados

al ver que la lluvia cae como lágrimas de fuego.

El sol de oro calienta el día. Las estrellas, astros

del cielo caminan...y sonríen porque la mañana

ya llegó.

\section{Pedazo de tierra}

Pedazo de tierra que me vio nacer, que me vio llorar. Fuiste destrozada por guerras, mas no apagaron tus tesoros.

Pedazo de tierra, te cuidaré, te sembraré árboles. Te daré oxígeno. Tú estás a mi lado

y te voy a honrar. Por eso digo:

Pedazo de tierra, jsiempre te debo amar!.

\section{Una mañana}

Una mañana de lluvia caía en lo infinito del mar.

Los árboles con silencio jovial dejaban las piedras hablar.

Luego el agua corría, se estremecía,

el lodo ignorado...pobre desviado,

era basura...

Deyvin David Espinoza Galeano, de 11 años de sexto grado. 


\section{Un sueño}

Yo estaba soñando.

En mi sueño:

una tormenta bajo del cielo

claro y sin fin.

Vi caer una perla

que deseaba recogerla.

Mi sueño era real.

El presente miré, en el

cielo una estrella.

Lejos estamos de la realidad.

Emerson Javier Gaitán de quinto grado, 11 años.

Fecha nac: 10/02/2004.

\section{Había una perla}

Había una perla cerca del mar, calló una lluvia, la llevó hasta lo infinito, estaba silenciosa...

Llegué yo...y me ignoró.

\section{Hay sonidos}

Hay sonidos sonoros.

Sonoros sueños.

La armonía de otoño.

Otoño en mi jardín.

Mi jardín da voces.

Voces con la lluvia.

Ixdalí Antonia Tercero Espinoza. Quinto grado. Fecha nac: 11/10/2005.

\section{Por las mañanas}

Por las mañanas he visto las nubes

pasando por los ríos.

También en los jardínes jugando

alegres...Es un sonoro canto.

Jendri Lidieth Pérez Amador.

Fecha nac: 12/04/2004. Quinto grado. 


\section{Mi sonrisa}

Mi sonrisa me extraña.

Mi mirada me fastidia.

Y todo lo que pienso

nada lo recuerdo.

Bertha Lidia Aguilar López.

Quinto grado. Fecha de nac:28/01/2004. 


\section{Alfredo Heber Masís 0.}

\section{Poseído}

Digo lo que siento, no sé qué pensarás.

Siento el frrío en las madrugadas

esperando el calor de tu amor.

El viento trae la lluvia, que te llevará

el mensaje del amor que te profeso:

Te amo no sé cómo decirlo, pero

sí estoy seguro que siempre te amaré.

No sé de ti le digo al viento,

lleva mi mensaje de amor a mi

amada, para que sepa que estoy

sufriendo su ausencia

¿Qué sientes tú?

Te hablan mis poemas

¿Te llaman?

La luna es testigo de mi desesperación,

me duermo y las lechuzas

me despiertan, con un sonido corto,

pero estridente y de regreso

el viento me trae el perfume

fragante de tu piel, que con cada

suspiro estremece mi corazón.

\section{Silencio}

Sé que estás triste, aunque ríes

me has dejado.

Te fuiste sin avisar, y tu silencio

señal de secuestro

¿Cómo saber qué sientes?

¿Qué piensas de mí y de ti?

Callando y esperando

te amo, la pasión me quema el pecho.

Te tomo porque me amas.

Cuéntame tus pesares.

Cuéntame tus alegrías.

¿Cómo saberlas?

Sólo di unas palabras:

para expresar amor

no se necesitan palabras.

Basta una mirada "Amor".

Que mi pensamiento te lo lleve el viento.

Que llegue a tu almohada

Que te aconseje lo que sabe:

¡Que hay en el sendero del amor!

¡Ven, ven, ven que necesito verte!

¡Por qué callas!
Fidelidad

Estoy viviendo para morir.

No te das cuenta de la realidad

o no quieres verla.

El silencio mata y el amor acaba.

El silencio que hemos creado

nos está poniendo a prueba y en apuros.

En los tiempos idos esto no tenía importancia, pero al acercarse el fin del camino sí.

Sin amor es como estar en el desierto sin agua.

Ver solo espejismos insondables

es creer en lo que no existe:

No dejemos el amor morir con el silencio.

El amor es vida.

Apresúrate, contesta ¿Qué esperas?

No seas tumba.

El silencio agazapado nos está matando.

La ilusión de que estemos juntos es alegría.

El alejamiento es agonía.

No quiero perderte:

Nuestro enemigo, el tiempo se ríe a carcajadas

$\mathrm{Ja}, \mathrm{ja}, \mathrm{ja}$, ja, porque

los que teníamos mucho:

Hoy estamos sin nada - ¡Estoy Pagándolas!

\section{Dilema}

Estoy como león enjaulado con la espera siendo fiel, con el corazón henchido de pasión, desperdiciando el tiempo con o sin razón. El pensamiento me trae recuerdos.

Es que las estoy pagando, cóbramelas que rebosante de amor está el caudal de mi cascada.

No me coloques a orilla del abismo que en el fondo están los peñascos donde se rompe el alma.

Qué no se marchite la flor del amor, qué no sean ilusiones perdidas.

¡Despierta ya! volvamos a la realidad.

El espejo del amor está reflejando un panorama inquietante de serenidad

que me asusta, y una fogata

que poco a poco se extinguirá

en el horizonte, un arcoíris delirante aparece

con una brisa reconfortante.

anunciando amor y placer

Ven que te estoy esperando. 


\section{A Escondidas}

Nuestro amor es escabroso. Los problemas son sociales, los podemos solucionar.

No tenemos culpa

¿Si le importamos a alguien?

son afectos familiares:

No les importan nuestros sentimientos, no, nos van ayudar ¿Cómo saberlo?

$¿ Y$ si decidimos unirnos libremente? ¿Qué pensarás y que pensarán? ¿Cómo saberlo? ¿qué dices?

¿Cómo haremos para vernos?

Por teléfono siempre alguien escucha.

No podemos hablar de amores inventando excusas para salir, levantando sospechas.

¿Ya te cansaste? ¿No lucharas o no quieres enfrentarte?

Tuvimos un alto en el camino; pero, regresando lo andado y arrepentido todo volvió a ser color de rosas.

Hoy se acerca la noche oscura Tú y yo somos lumbre en el camino ¿Cuándo nos podemos desnudar? 


\section{Kevin Uriel Ramírez Rivera}

\section{Eres mía}

La noche cae sigilosa, lenta e implacable las luces, la música, las cervezas parecen impávidas y se niegan a dormir bailas alegremente, contorsionándote y dedicándome una sonrisa te acercas, mi cuerpo vibra de pasión me pierdo en tu mirada, te siento mía susurras a mi oído, te deseo, te necesito salimos de aquel sitio, te recuestas en mi pecho: tu aroma de mujer me enloquece y despierta en mí esa esencia salvaje ¡Te beso, te tomo, eres mía!

\section{Gotas de dolor}

En lo profundo del lago del sufrimiento, bajo mil cadenas mi corazón até herido, maltratado, pisoteado con profundas cicatrices el amor no es para mi, me dije; ya no sufriré más que y así anduve por la vida, sin amor y sin fe hasta que apareciste en mi vida, y las llaves de mil cadenas en tus manos entregué y sacaste mi corazón de su angustia, letargo y soledad: lo cuidabas con cariño, lo estimabas de verdad y un día mientras soñaba con mi cuento de hadas tomaste mi corazón, y con ternura le clavaste el puñal de la traición, de la indiferencia y el desamor.

gotas de dolor, destilan de mi pecho mezcladas con amargas lágrimas de sufrimiento.

No hay amor, más que en los cuentos tarde me percaté. 


\section{Gustavo Madrigal Mendieta}

\section{Milagro Antilevítico}

Tórridas, lujuriantes y profusas auroras estallan en tu Ciclo, excitando mil bárbaras manías, y de costumbre, almibarando nuestra tregua, con la más dulce demencia.

Auroras (que también son crepúsculos alegóricos de un eterno abril) Inflaman tu braga.

Marinas puestas de sol (que también son auroras) declinan, como milagro antilevítico, en tu biósfera, excitando crónicamente la rabia de tu falda.

Y en ese horizonte diamantino, de naturaleza profusa y antagónica, cirros de hemoglobina, en un instante, estallan con la fuerza de un Big Bang;

Hemofílicos ensalmos y bálsamos

Seductores permean la felicidad de mi mundo en tu galaxia:

Donde vos sos mía, con la explosión de tus rubíes menstruales, en esas tardes candentes de un eterno abril, con sus puestas de sol, muy al ocaso, en un piélago escarlata, donde yo me sumerjo por entero y soy tuyo, todo completo, con demencia, lascivia y manías en combo. 


\section{Si yo hubiera nacido en Sepur Zarco}

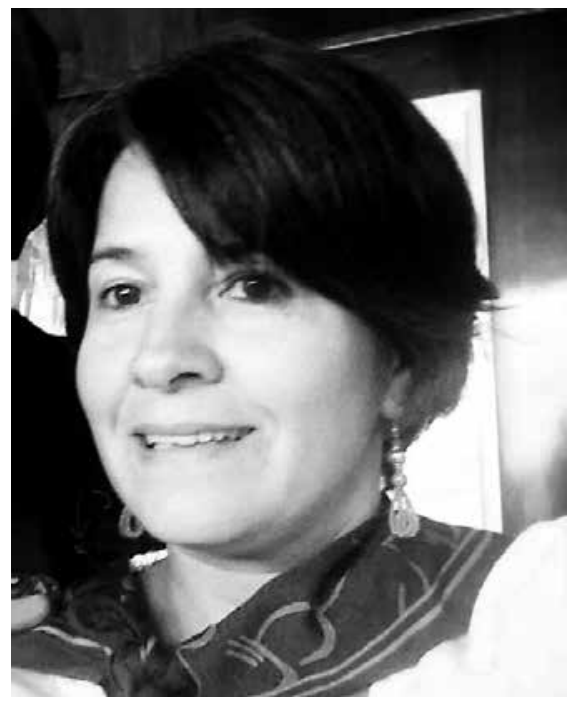

Brenda Solís Fong ${ }^{1}$

Poeta y escritora guatemalteca

Si yo hubiera nacido en Sepur Zarco

hablaría en Q'eqchí,

lloraría en Q'eqchí

y tendría una historia que contar.

Sería quizá, la hija de la viuda,

la chica de los doce años,

la esclava tierna del cuartel,

el juguete nuevo del cuartel.

Si yo hubiera nacido en Sepur Zarco

hoy sería esa mujer que juró verdad frente a un juez,

-seguramente no me creerías.-

Sí, sería la mujer que viste en las noticias, la del juicio

la del tapado amarillo y franjas negras en el rostro

la que llora y no se quiebra frente al juez Miguel.

La de los pies descalzos curados de caminos,

la que ensució sus plantas con gargajos de soldados,

la que bailó forzada, se desnudó y fue abusada por un ejército ebrio,

la obligada cada noche al mismo infierno y después a rezar.

La que madrugaba a tortear, lavar uniformes, asear el cuartel,

la que se convirtió sin saber, en esclava sexual y laboral.

Si hubiera nacido en Sepur zarco, sería esa valiente Q'eqchí,

la del juicio que hoy es noticia,

la mujer del tapado amarillo con franjas negras,

la que contó su historia de horror

a una patria dividida que no le cree su historia de horror.

Sería esa mujer que contó su historia y me sacó de mi zona de confort,

-Yo, mujer urbana, poeta de infancia feliz-. 